\title{
TREATMENT OF NON-GONOCOCCAL URETHRITIS FROM THE POINT OF VIEW OF COST AND EFFICIENCY*†
}

\author{
BY \\ G. JELINEK \\ Special Treatment Centre, St. Bartholomew's Hospital
}

This report is based on a series of 340 patients with non-gonococcal urethritis.

\section{Material}

The patients were divided into five groups:

(1) 53 patients were given Sulphatriad tablets $5 \mathrm{~g}$. daily for 5 days;

(2) 66 patients received a single injection of streptomycin sulphate ("Streptaquaine") $1 \mathrm{~g}$. with $25 \mathrm{~g}$. Sulphatriad over 5 days;

(3) 97 patients were given five daily injections of streptomycin sulphate ("Streptaquaine") $1 \mathrm{~g}$.;

(4) 48 patients were given tetracycline ("Ächromycin") $1 \mathrm{~g}$. daily (in four divided doses) for 4 days, a total of $4 \mathrm{~g}$.;

(5) 76 patients were given oxytetracycline ("Terramycin") in doses ranging from 5 to $7.5 \mathrm{~g}$. over 5 days.

\section{Method}

The patients were kept under observation for 3 months; they were then considered cured if they had no symptoms and showed no signs, the urine being clear, the prostatic fluid normal, and the serological tests for syphilis negative.

On their first attendance, all patients with urethritis had a scraping taken from the fossa navicularis which was examined for Trichomonas vaginalis; this was found to be positive in only one patient and he was excluded from this series.

All tests on the patients were carried out by the same individuals apart from a change of housemen; the other medical and nursing staff remained the same.

The cost of the course of treatment was calculated on the present price chargeable to a large teaching hospital (i.e. wholesale price, with a small reduction according to the amount purchased).

* Received for publication May 18, 1957.

+ Paper read before the M.S.S.V.D., London, on April 26, 1957.

\section{Results}

It will be noted that the two groups with the best results are those in the streptomycin with Sulphatriad and the oxytetracycline groups (Table I), but the former costs only $4 s .9 d$. and the latter costs between $28 s$. $8 d$. and $43 s$.

TABLE I

\begin{tabular}{|c|c|c|c|c|c|c|}
\hline \multirow[b]{2}{*}{ Drug } & \multirow{2}{*}{$\begin{array}{l}\text { Do- } \\
\text { sage } \\
\text { (g.) }\end{array}$} & \multicolumn{3}{|c|}{ No. of Cases } & \multirow{2}{*}{$\begin{array}{c}\text { Per } \\
\text { cent. } \\
\text { Cured }\end{array}$} & \multirow{2}{*}{$\begin{array}{c}\text { Present } \\
\text { Cost } \\
\text { of } \\
\text { Course }\end{array}$} \\
\hline & & Treated & $\begin{array}{c}\text { Fol- } \\
\text { lowed- } \\
\text { Up: }\end{array}$ & Failed & & \\
\hline Sulphatriad & 25 & 53 & 47 & 19 & 60 & 3s. $3 d$. \\
\hline 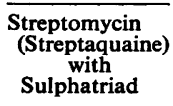 & $\begin{array}{r}1 \\
25\end{array}$ & 66 & 49 & 11 & 78 & 4s. $9 d$. \\
\hline $\begin{array}{l}\text { Streptomycin } \\
\text { (Streptaquaine) }\end{array}$ & 5 & 97 & 91 & 27 & 70 & $7 s .6 d$. \\
\hline $\begin{array}{l}\text { Tetracycline } \\
\text { (Achromycin) }\end{array}$ & 4 & 48 & 42 & 16 & 62 & $22 s .10 d$ \\
\hline $\begin{array}{l}\text { Oxy- } \\
\text { tetracycline } \\
\text { (Terramycin) }\end{array}$ & $5-7 \cdot 5$ & 76 & 67 & 16 & 77 & $\begin{array}{l}28 s .8 d . \\
\text { to } \\
43 s .\end{array}$ \\
\hline
\end{tabular}

\section{Comment}

Comparing these results with those achieved by various authors, the overall impression is that they are closely similar and there is no significant statistical difference in the sulphonamide, streptomycin with sulphonamide, and oxytetracycline groups. It seems that whatever treatment is given the results are much the same (see Table II opposite).

We did not introduce a control group without treatment into our series, but Fowler has done this and reported his results in a discussion at a meeting of the M.S.S.V.D. in Liverpool in the Autumn of 1956. He found that, with potassium citrate mixture alone, 78.7 per cent. of his patients were free from signs and symptoms at the end of 5 weeks' observation. His figures are comparable to the abovementioned ones, but until we know more about the 
TABLE II

PERCENTAGE RATES OF CURE

\begin{tabular}{c|c|c|c|c|c|c}
\hline Author & Date & $\begin{array}{c}\text { Sulpha- } \\
\text { triad }\end{array}$ & $\begin{array}{c}\text { Strepto- } \\
\text { mycin } \\
+ \\
\text { Sulpha- } \\
\text { triad }\end{array}$ & $\begin{array}{c}\text { Strepto- } \\
\text { mycin }\end{array}$ & $\begin{array}{c}\text { Tetra- } \\
\text { cycline }\end{array}$ & $\begin{array}{c}\text { Oxy- } \\
\text { tetra- } \\
\text { cycline }\end{array}$ \\
\hline Harkness & 1953 & - & - & 39 & - & 86 \\
\hline Lyall .. & 1953 & - & $85 \cdot 4$ & - & - & - \\
\hline Willcox .. & 1956 & $60 \cdot 4$ & - & $62 \cdot 1$ & $83 \cdot 5$ & $84 \cdot 1$ \\
\hline Prebble .. & 1957 & - & 76 & - & - & - \\
\hline Jelinek .. & 1957 & 60 & 78 & 70 & 62 & 77 \\
\hline
\end{tabular}

aetiology and natural history of non-gonococcal urethritis and have more statistics of the range of pathogens which cause it, we may assume that the majority of patients acquire the disorder through sexual contact. If we accept Fowler's figures, the patient with non-gonococcal urethritis may expect a spontaneous cure in almost four cases out of five, but this will take 5 weeks, during which time he may pass the infection to others; whereas, with treatment, the clinical response usually occurs in the first week.

\section{Summary}

Whatever initial treatment is used for nongonococcal urethritis the results are not dissimilar. The cheaper drugs, however, particularly streptomycin combined with sulphonamide, give as satisfactory a rate of cure as the much more expensive tetracyclines. On the other hand, the tetracyclines may be of use when a relapse occurs.

\section{REFERENCES}

Harkness, A. H. (1953). British Journal of Venereal Diseases, 29, 134. Lyall, T. (1953). Ibid., 29, 151.

Prebble, E. E. (1957). Ibid., 33, 43.

Willcox, R. R. (1956). Ibid., 32, 115. 